\title{
REVALUATION OF DIFFERENTIATION FEATURES IN THE GROUP PASTEURELLA - ACTINOBACILLUS
}

\author{
O. MRÁZ \\ Department of Epizootiology and Microbiology, University of Veterinary Science, 61242 Brno
}

Received August 2, 1982

\begin{abstract}
Mráz O.: Revaluation of Differentiation Features in the Group Pasteurella - Actinobacillus. Acta vet. Brno, 52, 1983: $77-82$.

The objective was to examine decisive criteria on the basis of which to differentiate in the group Haemophilus - Pasteurella - Actinobacillus, the criteria being the ones reported by Mannheim et al. (1980). From the results can be concluded:

1) In agreement with the above authors while applying their methods we failed in attempting to differentiate 26 collection (CCM) strains of pasteurellae and actinobacilli, whether with respect to the genera or to individual species.

2) Satisfactory results in these and 688 field strains were obtained when the diagnostic features were used in the following order: the growth ability on MacConkey's agar (BBL 11386), the formation of urease and indole, as well as the type of haemolysis and the fermentation of trehalose for actinobacilli in addition.
\end{abstract}

Actinobacilli, pasteurellae.

The Pasteurella and Actinobacillus genera developed from initial type species, namely P. multocida and $A$. lignieresii, as a consequence of different clinic and pathology of pasteurellosis and actinobacillosis. The alignment of further species was then more or less the result of subjective consideration which, in addition, occurred at the time when more refined biochemical tests were missing. Conceivably, their differentiation is not possible when based on the Bergey's Manual (Buchanan and Gibbons 1974) now available, so that the question of reassessing both these genera has come to the fore. Initiation of this paper was due to an article by Mannheim et al. (1980) in which the authors attempted to reclassify the group Haemophilus - Pasteurella - Actinobacillus while using indole reaction, sucrose fermentation, phosphatase formation, xylose fermentation and urease formation.

\section{Materials and Methods}

In view of the fact that the strains CCM of pasteurellae and actinobacilli had not been tested for phosphatase before, an attempt was by us to retest them using $3-5$ strains from each species (making a total of 26 strains) together with their examination for $\beta$-galactosidase, acetoin formation and ornithine decarboxylase. Moreover, the results in 688 field strains were included, which is evident from the following list:

P. gallinarum: CCM 5977, 6061, 6062 and further 40 strains from domestic fowl,

P. multocida: CCM 5419, 5420, 5902 and further 194 strains from man (29), cattle (20), sheep (2), goat (2), pig (47), dog (3), cat (4), rabbit (49), goose (1), domestic fowl (22), hare (2), mink (12) and nutria (1),

P. pneumotropica: CCM 5775, 5777, 5778 and further 118 strains from white rat (26) and white mouse (92),

P. ureae: CCM 5774, 5779, 5781 and further 71 strains from man (12), guinea-pig (19), white rat (8) and white mouse (32), 
A. equuli: CCM 5500, 5586 (received as A. suis), 5587 and further 43 strains from horse (9) and pig (34),

A. haemolyticus: CCM 5141, 5422, 5785 (all received as Pasteurella haemolytica) and further 65 strains from cattle (26) sheep (30) and pig (9),

$A$. haemolyticus subsp. indologenes: CCM 5684 (received as $A$. lignieresii), 5685 and further 24 strains from cattle,

A. lignieresii: CCM 5144, 5145, 5784 and further 97 strains from man (2), cattle (88) and sheep (7), and

A. salpingitidis: CCM 5974, 5975, 5976 and further 36 strains from domestic fowl (35) and turkey (1).

Indole formation was examined in $1 \%$ tryptone water. The 5-day culture was shaken with $0,5 \mathrm{ml}$ of Kovács's reagent (1928) and after $1 \mathrm{~min}$. the colour of the emulsion raised to the surface was evaluated.

Liquid medium for fermentation of carbohydrates contained $1 \%$ tryptose peptone, $0,5 \%$ $\mathrm{NaCl}, 0,1 \% \mathrm{Na}_{2} \mathrm{HPO}_{4}, 1 \%$ of appropriate carbohydrate and bromthymol blue as an indicator

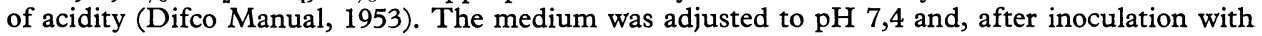
one drop of 24 -hr broth culture, incubated at $37^{\circ} \mathrm{C}$ for a period of 14 days.

The testing for phosphatase followed the method by Barber and Kuper (1951). This technique makes use of phenolphthalein diphosphate agar and the 18-hr culture is exposed to ammonia vapour. In positive cases the culture becomes reddish due to the action of liberated phenolphthalein.

Urease activity of strains was proved using the liquid modification of Christensen's medium (1946); to prepare this, the more nutritive proteose peptone was applied. The heavily inoculated test-tubes were placed in the thermostat and the results read in the course of five consecutive days.

The ONPG ( $\beta$-galactosidase) test was performed according to Lowe (1962); with respect to fastidious bacteria, tryptose peptone and greater inoculum were used.

Hydrogen sulphide production was estimated in nutrient broth enriched with $0.01 \%$ of cystine. Incubation of test-tubes and observation of inserted lead acetate paper covered a period of 7 days.

Unified MR - VP medium with proteose peptone according to Abd-el-Malek and Gibson (1948) was used for detection of acetoin. Incubation at $37^{\circ} \mathrm{C}$ lasted for 5 days. VP test was carried out using alpha naphthol and $\mathrm{KOH}$ (Barrit 1936).

Table 1

Classification of pasteurellae and actinobacilli (MANNHEIM et al., 1980 - modified)

\begin{tabular}{|c|c|c|c|c|c|}
\hline Indole & Saccharose & Phosphatase & Xylose & Urease & Genus and species \\
\hline \multirow{4}{*}{+} & \multirow{2}{*}{+} & \multirow{2}{*}{+} & \multirow{2}{*}{ V } & + & $P$ pneumotropica \\
\hline & & & & - & P. multocida \\
\hline & \multirow{2}{*}{-} & \multirow{2}{*}{-} & $(+)$ & V & $\begin{array}{l}\text { H. haemoglobino- } \\
\text { philus }\end{array}$ \\
\hline & & & - & $\mathrm{V}$ & H. somnus \\
\hline \multirow{8}{*}{ - } & \multirow{6}{*}{+} & \multirow{6}{*}{+} & \multirow{6}{*}{ V } & + & A. lignieresii \\
\hline & & & & + & A. equuli \\
\hline & & & & + & P. ureae \\
\hline & & & & - & P. haemolytica \\
\hline & & & & - & A. salpingitidis \\
\hline & & & & - & P. gallinarum \\
\hline & \multirow[b]{2}{*}{ - } & + & + & V & $\begin{array}{l}\text { A. actinomycetem- } \\
\text { comitans }\end{array}$ \\
\hline & & - & + & V & $\begin{array}{l}\text { A. seminis } \\
\text { H. agni }\end{array}$ \\
\hline
\end{tabular}

Comments :

()$=$ reaction delayed 
Ornithine decarboxylase was examined in a medium proposed by Møller (1955), in which the indicator was replaced by phenol and bromphenol red. After a heavy inoculation, the medium was incubated at $37^{\circ} \mathrm{C}$ and observed over four consecutive days.

\section{Results}

From Tab. 1 (modified) will be evident that Mannheim et al. failed in their attempt to separate haemophili, pasteurellae and actinobacilli by means of the above tests, which resulted in their scepticism concerning homogeneity of these genera in taxonomic respects.

Table 2

Application of criteria from Table 1 in CCM strains of pasteurellae and actinobacilli

\begin{tabular}{|c|c|c|c|c|c|c|c|c|}
\hline Genus and species & Indole & $\begin{array}{l}\text { Saccha- } \\
\text { rose }\end{array}$ & $\begin{array}{c}\text { Phospha- } \\
\text { tase }\end{array}$ & Xylose & Urease & ONPG & Acetoin & Ornithine \\
\hline $\begin{array}{l}P . \text { gallinarum } \\
P . \text { haemolytica } \\
P . \text { multocida } \\
P . \text { pneumotropica } \\
P . \text { ureae }\end{array}$ & $\begin{array}{l}- \\
\overline{+} \\
+ \\
-\end{array}$ & $\begin{array}{l}+ \\
\mathrm{v} \\
+ \\
+ \\
+\end{array}$ & $\begin{array}{l}+ \\
\dot{+} \\
\mathrm{v} \\
+ \\
+\end{array}$ & $\begin{array}{l}\mathrm{V} \\
\mathrm{V} \\
\mathrm{V} \\
+ \\
-\end{array}$ & $\begin{array}{l}- \\
-- \\
\overline{+} \\
+\end{array}$ & $\begin{array}{l}\mathrm{V} \\
\mathrm{V} \\
\frac{1}{+}\end{array}$ & $\begin{array}{l}\overline{\mathrm{V}} \\
\mathrm{V} \\
\mathrm{V} \\
-\end{array}$ & $\begin{array}{l}\bar{v} \\
+ \\
+ \\
+\end{array}$ \\
\hline $\begin{array}{l}\text { A. equuli } \\
\text { A. lignieresii } \\
\text { A. salpingitidis }\end{array}$ & $\bar{z}$ & $\begin{array}{l}+ \\
+ \\
+\end{array}$ & $\begin{array}{l}+ \\
+ \\
+\end{array}$ & $\begin{array}{l}\mathrm{V} \\
+ \\
+\end{array}$ & $\begin{array}{l}+ \\
\pm \\
+\end{array}$ & $\begin{array}{l}+ \\
+ \\
+\end{array}$ & $\begin{array}{l}\mathrm{V} \\
\mathrm{v}\end{array}$ & $\stackrel{+}{-}$ \\
\hline
\end{tabular}

Using the same criteria, it must be admitted that we were not succesful either, as may be evident from Tab. 2. In addition, we were able to confirm the fact that not only phosphatase (and this in particular), but also $\beta$-galactosidase were enzymes the nature of which was too common here to be utilized for a more distinct bacterial differentiation.

Table 3

Differentiation of pasteurellae

\begin{tabular}{|c|c|c|c|c|c|c|c|}
\hline \multicolumn{7}{|c|}{ Diagnostic features } & \multirow{2}{*}{ Species } \\
\hline MacConkey & Urease & Indole & Ornithine & Lactose & Maltose & $\mathrm{H}^{2} \mathrm{~S}$ & \\
\hline- & - & + & + & - & $\mathrm{V}$ & + & \multirow{5}{*}{$\begin{array}{l}P . \text { multocida } \\
P . \text { gallinarum } \\
P . \text { pneumotropica }\end{array}$} \\
\hline- & - & - & - & - & + & + & \\
\hline- & + & + & $\mathrm{V}$ & $\left.V^{1}\right)$ & $\left.+^{1}\right)$ & + & \\
\hline - & + & - & - & - & - & $-2)$ & \\
\hline - & + & - & $\mathrm{V}$ & $\mathrm{V}$ & $\mathrm{V}$ & $+3)$ & \\
\hline
\end{tabular}

Comments: ${ }^{1}$ ) $=$ some reactions delayed

2) = human strains

s) $=$ rodent strains

On the other hand, the experience obtained by us has suggested that after transferring Pasteurella haemolytica into the genus Actinobacillus (Mráz 1969; Pohl 1981), not only the studied genera are distinguishable but also individual species 
within the respective genus can be determined. For a classification of this kind, the growth ability on MacConkey's agar BioQuest (Mráz 1975) can be employed as a starting point; while within the genera the formation of urease and indole is applicable, the type of haemolysis and the fermentation of trehalose for actinobacilli in addition, will serve the purpose (Tabs. 3 and 4).

Table 4

Differentiation of actinobacilli

\begin{tabular}{|c|c|c|c|c|c|c|c|}
\hline \multicolumn{7}{|c|}{ Diagnostic features } & \multirow[b]{2}{*}{ Species } \\
\hline MacConkey & Urease & Indole & $\begin{array}{l}\text { Haemolysis } \\
\text { of ovine } \\
\text { erythrocytes }\end{array}$ & $\begin{array}{c}\text { Haemolysis } \\
\text { of lamb } \\
\text { erythrocytes }\end{array}$ & Trehalose & Lactose & \\
\hline+ & + & - & - & - & - & $\left.V^{1}\right)$ & A. lignieresii \\
\hline+ & + & - & $\begin{array}{l}\text { whole } \\
\text { or - }\end{array}$ & $\begin{array}{l}\text { whole } \\
\text { or - }\end{array}$ & + & $\left.V^{2}\right)$ & A. equuli \\
\hline+ & - & - & whole & whole & + & $\left.+{ }^{3}\right)$ & A. salpingitidis \\
\hline+ & - & - & $\alpha^{\prime}$ or - & $\begin{array}{l}\text { double } \\
\text { (whole } \\
\text { and } \alpha^{\prime} \text { ) }\end{array}$ & $\mathrm{v}$ & $\mathrm{v}$ & A. haemolyticus \\
\hline+ & - & + & $\alpha^{\prime}$ or - & $\begin{array}{l}\text { double } \\
\text { (whole } \\
\text { and } x^{\prime} \text { ) }\end{array}$ & $\mathrm{v}$ & $\mathrm{v}$ & $\begin{array}{l}\text { A. haemolvticus } \\
\text { subsp. indologevies }\end{array}$ \\
\hline
\end{tabular}

Comments: ${ }^{1}$ ) $=$ in positive cases after $24 \mathrm{hrs}$

$\left.{ }^{2}\right)=$ in positive cases till $24 \mathrm{hrs}$

3) = all reactions delayed

\section{Discussion}

It is to be admitted that the study conducted with groups each consisting of 3-5 collection strains meant a contribution, but it could not cover the whole range of potential variability. For this reason the results were documented also by 12 to 60 multiplies of field strains that had been examined in this laboratory during the past ten years. The aerogenic isolates (8 strains) from nasopharynx of healthy guinea-pigs were not included, but in characteristics they corresponded to $\mathrm{H}_{2} \mathrm{~S}$ positive biovar of $P$. ureae.

As for the methods, the growth ability on MacConkey's agar seemed to be a most delicate feature, although only the selection of the convenient medium was the matter. However, the mention of the BBL agar is intended to point out mainly the fact that such a medium can be prepared, and that its selectivity is at a high level already. Neither any special difficulties occurred with the setting up of a classification scheme. Basing on the experience with different carbohydrates the hydrolysis of urea is taken as ranking first, for it yields quick and unambiguous results.

In conclusion, we want to add that the work done so far by Mannheim and his collaborators has been appreciated. With this paper we only wish to contribute to the solution of a new family in statu nascendi. 


\section{Zhodnocení diferenciačních znaků ve skupině Pasteurella - Actinobacillus}

$\mathrm{V}$ práci byla zkoumána rozhodující kritéria $\mathrm{z}$ taxonomické studie Mannheima et al. (1980) o diferenciaci ve skupině Haemophilus - Pasteurella - Actinobacillus.

$\mathrm{Z}$ upravené tabulky č. 1 je zřejmé, že se těmto autorům nepodařilo osamostatnit žádný $\mathrm{z}$ uvedených rodů, takže upadají do skepse, zda jde o taxonomicky homogenní rody.

Za použití stejných kritérií u sbírkových kmenů pasteurel a aktinobacilů CCM se to nepodařilo ani nám, jak je vidět na tabulce č. 2. Navíc jsme mohli konstatovat, že zejména fosfatáza, ale i $\beta$-galaktozidáza jsou zde přiliš častými enzymy, než aby mohly sloužit $\mathrm{k}$ výraznější diferenciaci jednotlivých rodů.

Naše vlastní zkušenosti u těchto a dalších 688 terénních kmenů však ukazují, že po převedení druhu Pasteurella haemolytica do rodu Actinobacillus (Mráz 1969; viz též Pohlová 1981) lze odlišit nejen oba rody, ale také jednotlivé druhy. Východiskem takové klasifikace je růstová schopnost na MacConkeyově agaru BioQuest (Mráz 1975), zatímco v rámci rodů je to vyšetření na ureázu a indol, u aktinobacilů také typ hemolýzy a zkvašování trehalózy (tabulka č. 3 a 4).

\section{Оценка различительных знаков в группе Pasteurella - Actinobacillus}

В работе мы исследовали решающие критерии таксономической работы M a n n e i m et al. (1980) о дифференциации в группе Haemophilus Pasteurella - Actinobacillus.

Из поправленной таблицы № 1 видно, что авторам не удалось изолировать никакой из приведенных родов, так что скептически выражают мнение, относятся ли они к таксономически гомогенным родам.

При использовании одинаковых критерий у коллекционных штаммов пастерелл и актинобацилл ССМ это не удалось ни нам, как изображено в таблице № 2. Сверх того мы могли констатировать, что в особенности фосфатаза, как и $\beta$-галактозидаза является слишком часто энзимами, то значит, не могут служить для выразительной дифференциации отдельных родов.

Наши собственные опыты у приведенных и дальнейших 688 штаммов показывают, что после переведения вида Pasteurella haemolytica к роду Actinobacillus (M r áz, 1969; P o h l, 1981) возможно отличить не только оба рода, но и отдельные виды. Выходом такой классификации является способность к росту на MacConkey агаре BioQuest (Mráz, 1975), между тем как в рамках родов исходным является испытание по уэразе и индолу, у актинобацилл тоже тип гемолиза и ферментация трегалозы (таблица № 3 и № 4 ).

\section{References}

ABD-EL-MALEK, Y. - GIBSON, T.: Studies in the bacteriology of milk. II. The staphylococci and micrococci of milk. J. Dairy Res., 15, 1948: 249.

BARBER, M. - KUPER, S. W. A.: Identification of Staphylococcus pyogenes by the phosphatase reaction. J. Path. Bact., 63, 1951: 65.

BARRIT, M. M.: The intensification of the Voges-Proskauer reaction by the addition of alpha naphthol. J. Path. Bact., 42, 1936: 441-454. 
BUCHANAN, R. E. - GIBBONS, N. E.: Bergey's Manual of Determinative Bacteriology. VIII. ed., Williams and Wilkins, Baltimore 1974. Pp. 1246.

Difco Manual of Dehydrated Culture Media and Reagents for Microbiological Laboratory Procedures. IX. ed., Detroit 1953. PP. 350.

CHRISTENSEN, W. B.: Urea decomposition as a means of differentiating Proteus and paracolon cultures from each other and from Salmonella and Shigella types. J. Bact., 52, 1946: $461-466$.

KOVÁCS, N.: Eine vereinfachte Methode zum Nachweis der Indolbildung durch Bakterien. Ztschr. Immunitätsforsch., 55, 1928: $311-315$.

LOWE, G. H.: The rapid detection of lactose fermentation in paracolon organisms by the demonstration of $\beta$-D-galactosidase. J. Med. Lab. Techn., 19, 1962: 21.

MANNHEIM, W. - POHL, S. - HOLLÄNDER, R.: Zur Systematik von Actinobacillus, Haemophilus und Pasteurella: Basenzusammensetzung der DNS, Atmungschinone und kulturellbiochemische Eigenschaften repräsentativer Sammlungsstämme. Zbl. Bakt., I. Abt., Orig. A 246, 1980: 512-540.

MØLLER, V.: Simplified tests for some amino acid decarboxylases and for the arginine dihydrolase system. Acta path. microbiol. scand., 36, 1955: 158.

MRÁZ, O.: Vergleichende Studie der Arten Actinobacillus lignieresii und Pasteurella haemolytica III : Actinobacillus haemolyticus (Newscm und Cross, 1932) comb. nov. Zbl. Bakt., I. Abt., Orig. 209, 1969: $349-364$.

MRÁZ, O.: Differentiation possibilities between pasteurellae and actinobacilli. Acta vet. Brno, 44, 1975: 105-113.

POHL, S.: DNA relatedness among members of Haemophilus, Pasteurella and Actinobacillus. In: KILIAN, M. - FREDERIKSEN, W. - BIBERSTEIN, E. L.: Haemophilus, Pasteurella and Actinobacillus. Academic Press, London 1981. Pp. 294. 